\title{
Changes in Phytochemicals during Processing of Green Tea
}

\author{
Madhusmita Neog, Priyanka Das* and Gautam Kumar Saikia \\ Department of Biochemistry and Agricultural Chemistry, \\ Department of Tea Husbandry and Technology, Assam Agricultural University, \\ Jorhat -785013, Assam, India \\ *Corresponding author
}

\section{A B S T R A C T}

Keywords

Green tea

processing, total phenols, ascorbic acid, chlorophyll, antioxidant activity, ash

Article Info

Accepted:

15 December 2019

Available Online:

20 January 2020
Considering lack of research on biochemical analysis of green tea manufactured by gradually increasing small tea growers of Assam and to know the changes of the phytochemicals taking place during traditional processing, the present investigation was carried out. The present investigation revealed that the phytochemicals in green tea changed significantly during processing from fresh leaves to final product. Due to processing, the constituents like ash, total chlorophyll content, total phenol, ascorbic acid and antioxidant activity in terms of DPPH scavenging decreased from $5.90 \%$ to $4.19 \%, 1.82 \mathrm{mg} / \mathrm{g}$ to $0.67 \mathrm{mg} / \mathrm{g}, 48.70$ $\%$ to $20.72 \%, 45.90 \mathrm{mg} / 100 \mathrm{~g}$ to $9.31 \mathrm{mg} / 100 \mathrm{~g}$ and $83 \%$ to $76.02 \%$, respectively. Boiled, rolled and dried green tea samples revealed the highest content of ascorbic acid $(14.63 \mathrm{mg} / 100 \mathrm{~g})$ and antioxidant activity in terms of DPPH scavenging $(84.17 \%)$ among four types of final products of green tea. The highest total phenol content $(24.55 \%)$ was found in green tea processed through boiling, rolling and pan firing and the highest $(0.85 \mathrm{gm} / \mathrm{g})$ chlorophyll content was found in steamed, rolled and pan fired green tea.

\section{Introduction}

Assam produces about $51 \%$ of the tea produced in India and about 1/6th of the tea produced in the world. India produced around 1267 million $\mathrm{kg}$ of tea in 2016-17 (Anonymous, 2017). Though, Assam is well known for black tea, small tea growers in Assam and other North Eastern states of India have started making green tea. The concept of small tea garden (STGs) is a recent phenomenon and the first small tea garden was established in Sivasagar District (present Golaghat district) of Assam in the year 1978. The concentration of small tea garden is the largest in Assam followed by West Bengal, Tamil Nadu, Kerala, Tripura, Arunachal Pradesh, Himachal Pradesh, Mizoram, Meghalaya and Bihar (Goowalla et al., 2015). Green tea components possess antioxidants, 
antimutagenic, and anticarcinogenic activity (Lui et al., 2008). Green tea consumption has also been linked to the prevention of many types of cancer, including lung, colon, esophagus, mouth, stomach, small intestine, kidney, pancreas, and mammary glands (Koo et al., 2004).

Green tea is sold as fresh or dried unfermented leaves. In green tea production, the young leaves are not allowed to oxidize. Instead, they are heated, which inactivates the enzymes (i.e. polyphenol oxidase), thus preserving the polyphenols. The fresh green leaves are steamed or boiled, rolled, and finally dried or pan-fired. The way the tea leaves are rolled determines the ultimate flavour of the tea. Another factor that decides the quality of the green tea is the plucking standard followed. Tender tea leaves and buds are manually plucked by skilled women workers from the tea plants after a fixed duration. Ideal plucking period for making a good quality green tea is 5-8 days (Rahman et al., 2013).

Green tea is processed using either artisanal or modern method. Sun drying, basket or charcoal firing or pan firing are common artisanal methods and oven drying, tumbling or steaming are common modern methods. In Assam, besides modern method, different traditional methods of manufacturing green tea are also popular among different ethnic groups of Assam.

Quality of tea is mainly reflected in its smell and taste, which are generated by volatile and non-volatile organic compounds present in the tea. The concentration of foliar chemical compounds has an important impact on the tea infusions flavour, smell and other factors that make up the tea quality (Chen et al., 2008).

The chemical composition of tea depends on growth of the plants, clones of tea, horticultural practices, soil, growth altitude, plucking season, sorting, grading, manufacturing or processing methods such as extraction, storage and drying of tea (Choudhury, 2010). Polyphenols content, the content of PPO (polyphenol oxidase) enzyme showed variation among different tea clones, which also influenced the final tea quality, and the ratio between PPO and its substrate (catechins) was used to characterize the potential quality of tea clones. In Assam, among Tocklai vegetative (TV) clones, TV 1,TV 9,TV 19,TV 23 and TV 26 are very popular among tea growers. TV 23 was found to be highly tolerant to drought among the TV clones. Moreover, TV 23 has also been reported to have high yield and average quality and is also one of the most preferred clones by the present day tea growers of North-East India.

The polyphenol have the highest concentrations in fresh leaves. As the leaves are heated, rolled, and dried during processing, the catechin content decreases as leaves undergo oxidation, hydrolysis, polymerization and transformation. Chlorophyll, the main pigment in fresh and dried tea leaves, is reduced by approximately half from fresh shoots to dried shoots by increased temperature, and hydrolysis (Xu and Chen, 2002). The application of heat during processing also causes the oxidation of watersoluble flavonols, which contribute to the yellow color of green tea infusions.

Considering lack of information on quality of green tea as influenced by the phytochemicals and the changes of these phytochemicals during processing of green tea produced in Assam, the present study was done.

\section{Materials and Methods}

The traditional processing methods followed for the green tea manufacture in Assam were already documented by us (Neog et al., 2018). 
The fresh tea leaves of clone TV 23 and traditionally manufactured four types of green tea samples as mentioned below and shown in Fig 1 were collected during $4^{\text {th }}$ Flush (October to mid November) from a small tea grower Shri Basanta Duwara of Geleki, Sivsagar, Assam.

Traditionally manufactured : Boiling, rolling and drying

Traditionally manufactured : Boiling, rolling and pan firing

Traditionally manufactured : Steaming, rolling and drying

Traditionally manufactured: Steaming, rolling and pan firing

Tea leaves for green tea were plucked at the age of 6-8 days (a leaf and a bud) in two days interval.

The ash content was determined as described in the AOAC (2002). The total chlorophyll content was determined by the method of Arnon (1949). The phenol content was determined by Folin-ciocateu method given by Bray and Thorpe (1954). The antioxidant activity was measured according to Molynux et al., 2012 using DPPH (2,2 diphenyl-1picrylhydrazyl) reagent. Ascorbic acid or vitamin $\mathrm{C}$ content was determined by the method described by AOAC (2002).

\section{Results and Discussion}

\section{Changes in phytochemicals during processing}

The phytochemicals viz. the ash content, total chlorophyll content, total phenol content, ascorbic acid content and antioxidant activity (in terms of DPPH scavenging) of green tea of fourth flush as affected by various traditional processing methods are presented at Table 1 and FIG. 2-6.

The ash content, total phenol, ascorbic acid, chlorophyll content and antioxidant capacity of fresh tea leaves of TV 23 clone decreased during various manufacturing steps including heating (boiling or steaming), rolling, drying or pan firing. The ash content can be altered due to loss of inorganic constituents during manufacturing step such as rolling (due to loss of juice).

Astill et al., (2001) observed that as the leaves are heated, rolled, and dried during processing, the polyphenol and catechin content decreased as leaves undergo oxidation, hydrolysis, polymerization and transformation. These results $(20-30 \%$ loss in polyphenol) were in agreement with the earlier observation of a processed tea product with at least $15 \%$ less polyphenol content than freshly plucked tea leaves (Astil et al., 2001). The chlorophyll content also decreased during processing as compared to fresh leaves. The observed decrease in chlophyll for the present finding too, is well supported by earlier findings (Xu and Chen, 2002), who suggested that the chlorophyll was reduced by approximately half from fresh shoots to dried shoots during processing (increased temperature, and hydrolysis).

However, absence of any particular pattern in content of ash during processing might be attributed to heterogeneous composition of leaves sample regarding age which was used to process. Earlier, the effect of leaf age on biochemical constituent of tea were reported by Mitscher and Dolby (1997), Rahman et al., (2013) and Prawira et al., (2018). Detection of higher content of certain biochemical constituents at some of the steps of processing than those detected for the fresh leaves (expressed on dry weight basis) might be 
attributed to mere increase in percentage, not actual increase in content. This increase in percentage might be due to loss of some other biochemical components during processing. It has been already reported that processing of tea involved loss of some dry matter components (Ruon et al., 2010; Chen et al., 2008; Wilson and Clifford, 1992 and Dang, 2005). Boiling/steaming made the leaves softer which enhanced increased loss of water soluble components during rolling.

Table.1 Changes of phytochemicals during processing of green tea

\begin{tabular}{|c|c|c|c|c|c|c|c|c|c|}
\hline $\begin{array}{c}\text { Phyto } \\
\text { chemicals } \\
\text { (On dry } \\
\text { weight basis) }\end{array}$ & $\begin{array}{l}\text { Fresh } \\
\text { leaves }\end{array}$ & $\begin{array}{l}\text { Boiled } \\
\text { leaves }\end{array}$ & $\begin{array}{c}\text { Steamed } \\
\text { leaves }\end{array}$ & $\begin{array}{l}\text { Boiled } \\
\text { \& } \\
\text { Rolled } \\
\text { leaves }\end{array}$ & $\begin{array}{c}\text { Steamed } \\
\text { \& Rolled } \\
\text { leaves }\end{array}$ & $\begin{array}{c}\text { Boiled, } \\
\text { rolled } \\
\& \\
\text { dried } \\
\text { leaves }\end{array}$ & $\begin{array}{c}\text { Boiled, } \\
\text { rolled } \\
\text { \&pan } \\
\text { fired } \\
\text { leaves }\end{array}$ & $\begin{array}{c}\text { Steamed, } \\
\text { rolled \& } \\
\text { dried } \\
\text { leaves }\end{array}$ & $\begin{array}{c}\text { Steamed, } \\
\text { rolled \& } \\
\text { pan fired } \\
\text { leaves }\end{array}$ \\
\hline $\operatorname{Ash}(\%)$ & 5.90 & 4.67 & 5.47 & 4.30 & 5.17 & 4.19 & 4.31 & 4.51 & 5.78 \\
\hline $\begin{array}{c}\text { Chlorophyll } \\
\text { content }(m g / g)\end{array}$ & 1.82 & 0.98 & 1.17 & 0.84 & 1.10 & 0.67 & 0.80 & 0.80 & 0.85 \\
\hline $\begin{array}{l}\text { Total phenol } \\
\text { content }(\%)\end{array}$ & 48.70 & 34.40 & 39.80 & 31.30 & 36.50 & 23.31 & 24.55 & 22.20 & 20.72 \\
\hline $\begin{array}{l}\text { Ascorbic acid } \\
\text { content } \\
\text { (mg/100g) }\end{array}$ & 45.90 & 22.34 & 19.17 & 19.62 & 15.90 & 14.63 & 11.17 & 10.64 & 9.31 \\
\hline $\begin{array}{l}\text { Antioxidant } \\
\text { activity, in } \\
\text { terms of } \\
\text { DPPH } \\
\text { scavenging } \\
(\%)\end{array}$ & 83.00 & 82.47 & 80.02 & 79.23 & 76.40 & 84.17 & 78.46 & 76.02 & 78.91 \\
\hline
\end{tabular}

Fig.1 Green tea manufacturing process followed in traditional unit ( Neog et al., 2018 )

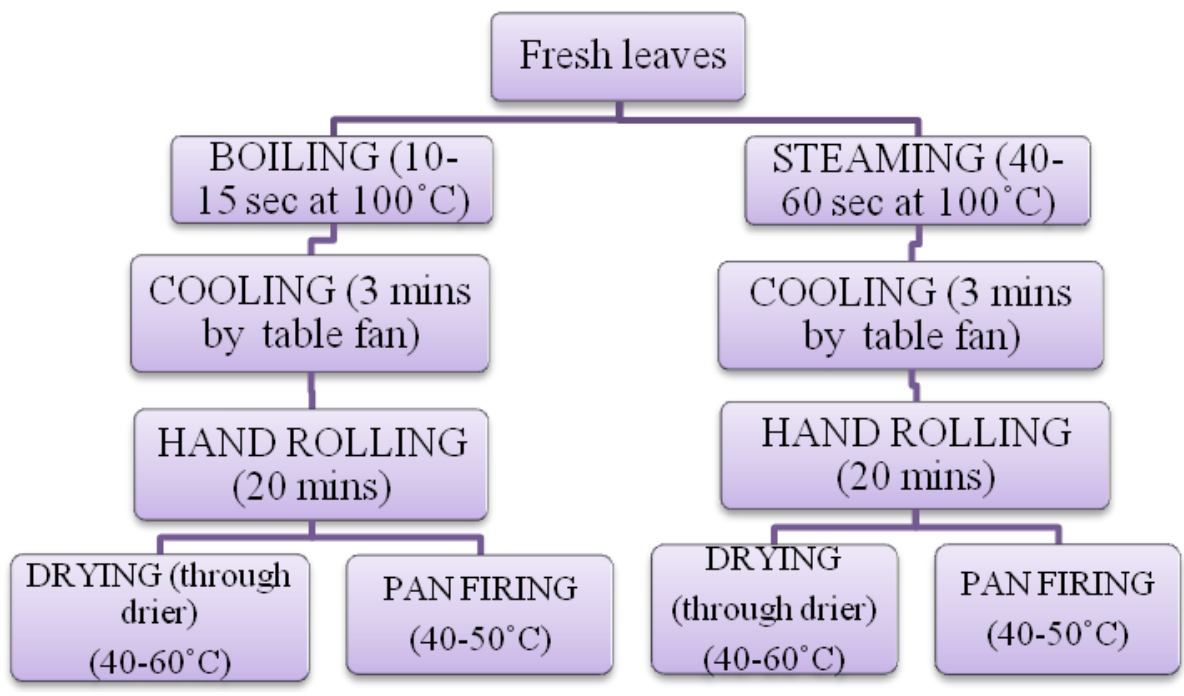


Fig.2 Ash Content (\%, Dry Basis) of Green Tea

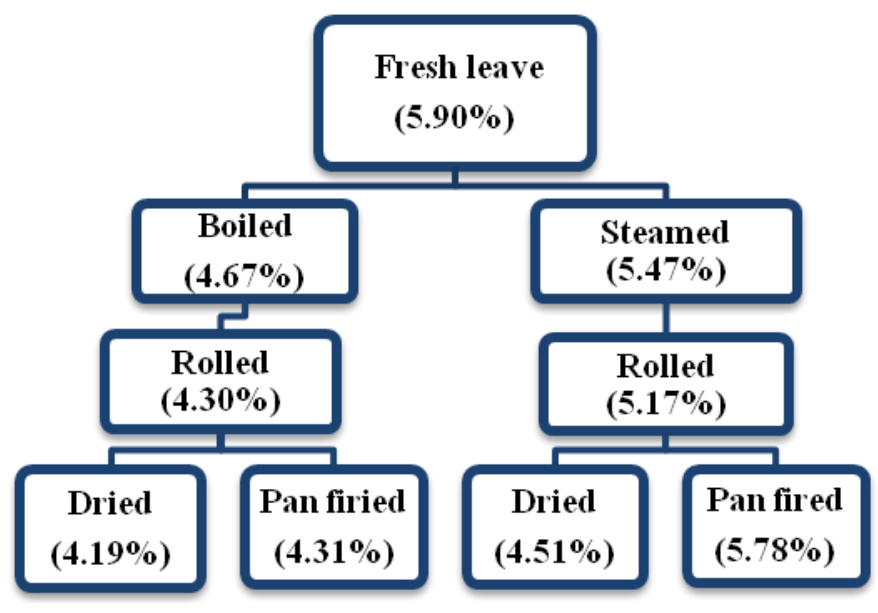

Fig.3 Chlorophyll Content (mg/G, Dry Basis) of Green Tea

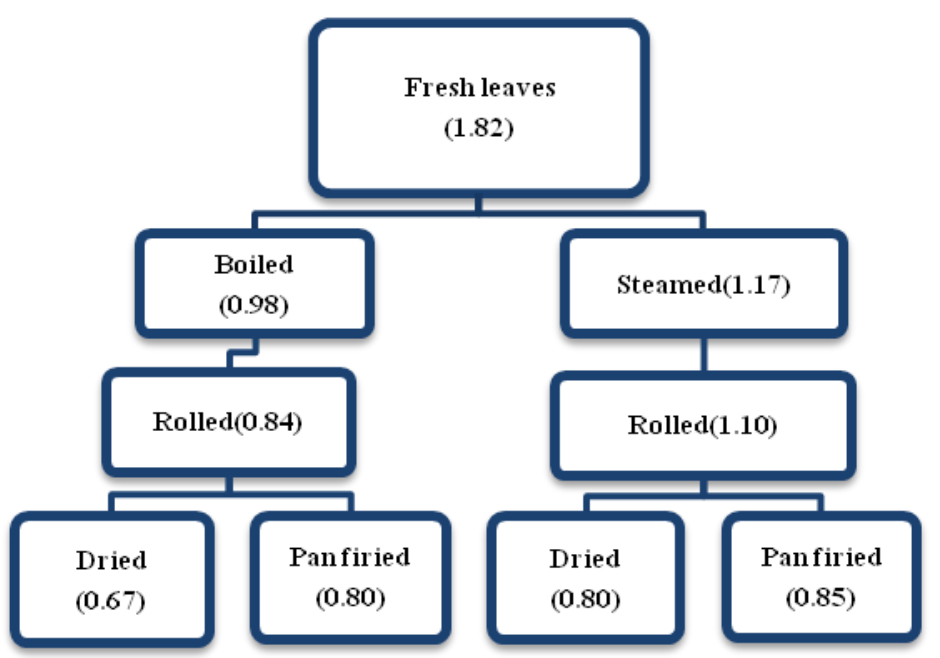

Fig.4 Antioxidant Activity(\%,Dry Basis) of Green Tea

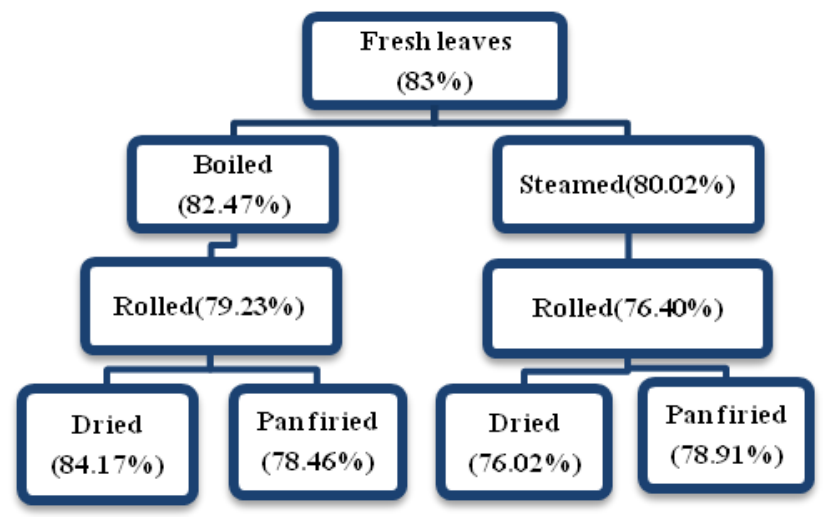




\section{Phytochemicals in final product (green tea made during fourth flush)}

In the present study, the ash content of the final products of green tea processed through four different methods ranged from $4.19 \%$ to 5.78\%. Jayawardhane et al., (2017) reported that ash content of some green tea of Sri Lankan market, ranged from 5.0 to $6.6 \%$. Ivanisova et al., (2018) observed that ash content of green tea ranged from 2.13 to 2.36\%. Maheshwari and Ramchandani (2018) reported the ash content of green tea to be from 4.05 to $5.97 \%$.

Ostadalova et al., (2015) observed that the chlorophyll content is an indicator of freshness. The present findings, chlorophyll content $(0.67 \mathrm{mg} / \mathrm{g}$ to $0.85 \mathrm{mg} / \mathrm{g})$ was found to be lower than those $(1.12-1.89 \mathrm{mg} / \mathrm{g}, 1.18-$ $2.41 \mathrm{mg} / \mathrm{g}$ and $1.59-2.15 \mathrm{mg} / \mathrm{g}$ ) reported by Gogoi and Baruah (2017), Hazarika and Mahanta (2000) and Prawira et al.,(2018), respectively.

The special flavour and astringency of a tea brew is the result of the total tea phenol, which amount to 18-36 percent of the weight of the total dry matter of a tea leaf (Graham,1992). In the present study, the total phenol content of the final products of green tea processed through four different methods ranged from $20.72 \%$ to $24.55 \%$. The total phenol content was found to be $30-40 \%, 11.9-25.2 \%$ and $29.93 \%$ as reported by Balentine et al.,(1997), Conrad et al., (2011) and Baruah et al.,(2012), respectively.

The present finding of ascorbic acid content $(9.31 \mathrm{mg} / 100 \mathrm{~g}$ to $14.63 \mathrm{mg} / 100 \mathrm{~g})$ was found to be comparable with those $(21-48 \mathrm{mg} / 100 \mathrm{~g}$ and $3-178 \mathrm{mg} / 100 \mathrm{~g}$ ) reported by Rahman et al., (2013) and Somanchi et al., (2017), respectively.

In the present study, the antioxidant activity as expressed in terms of DPPH scavenging was found to be $76.02 \%$ to $84.17 \%$. Earlier, $92.1 \%, 69 \%, 88.3-94.3 \%$ activity were reported by Yashin et al.,(2011), Obaidi and Sahib (2015) and Karori et al., (2014), respectively.

Among the traditional manufacturing processes of green tea of Assam, it was observed that the highest amount of losses of total phenol and ascorbic acid were associated with steaming and pan firing, while those of ash and chlorophyll content were associated with boiling and drying. The loss for antioxidant activity was the maximum for the process steaming and drying. The antioxidant activity can be positively correlated with ascorbic acid and total phenol content. The boiling method of inactivation of enzymes is more efficient in comparison to steaming for better retention of green tea phytochemicals viz total phenols and ascorbic acid.

\section{References}

Anonymous.2017. The Tea Board of India, $63^{\text {rd }}$ Annual Report 2016-17, Kolkata.

A.O.A.C. 2002.Official Methods of Analysis. $10^{\text {th }}$ Ed. Association of Analytical Chemists, Washington D.C.

Arnon, D.I. 1949. Copper enzymes in isolated chloroplasts. Polyphenoloxidase in Beta vulgaris. Plant Physiol. 24: 1-15.

Astill, C., Birch, M. R., Dacombe, C., Humphrey, P. G. and Martin, P. T. 2001. Factors Affecting the Caffeine and Polyphenol Contents of Black and Green Tea Infusions. J Agr Food Chem, 49:5340-5347.

Balentine, D. 1997. Tea and Health. Crit. Rev. Fd Sci. Nutr, 37: 691-692.

Barua, D. N. 1964. Selection of Vegetative Clone. Two and a Bud, 11:32-38.

Baruah, S., Bordoloi, A. K., Gogoi, R. C., Gogoi, M. K. and Hazarika, M. 2012.An integrated approach to the 
extraction of natural tea color, flavor and evaluation of antioxidant properties of tea. Two and a Bud, 59(2):126-129.

Bray, H. G. and Thorpe, W. V. 1954. Analysis of Phenolic Compounds of Interest in Metabolism. Methods Biochem. Anal.,1: 27-52.

Chaudhury, M., Bhawani, S., Fong, S. S. and Mohamad I. 2010. Spectrophotometric analysis of caffeine. International $\mathrm{J}$. analytical chemistry, 2015.

Chen, H., Zhang, M., Qu, Z. and Xie, B. 2008. Antioxidant activities of different fractions of polysaccharide conjugates from green tea (Camellia Sinensis). Food Chemistry, 106(2):559-563.

Cornad, A., Mark, R. B., Clive, D. and Philip, G. H.2011.Factors Affecting the Caffeine and Polyphenol Contents of Blackand Green Tea Infusions. J. Agric. Food Chem., 49: 5340-5347.

Dang, F., Gonçalves, A. E. D. S. S., Lajolo, F. M. and Genovese, M. I. 2005. Flavonoids, total phenolics and antioxidant capacity: comparison between commercial green tea preparations. Food science and technology (campinas), 30 (4):10771082.

Gogoi, A. S. and Borua, P. K. 2017. Profiling of total polyphenols and pigments in tea (camelliasinensis (1.) O. Kuntze) in various seasons for mmanufacturin black tea and green tea. International J. of Food and Nutritional Sc.,6(2):123134.

Graham, H. N. 1992. Green tea composition, consumption and polyphenol chemistry. Prev. Med., 21:334-350.

Hazakira, M. and Mahanta, P. K. 2000.Composition Changes in Chlorophylls and Carotenoids During the Four Flashes of Tea in NE India. J. Science and Food Agriculture, 35: 298-303.
Harlan, V., Musa, A. and Yakasai, I.1995. Spectrophotometric method for determination of catechins in green tea and herbal formulations. Nig. Journ. Pharm. Sci., 16(1):25-30.

Ivanisova, A., Butt, M. S., Yasin, M., Imran, M., Batool, R. and Naz, A. 2018. Phytochemical screening of different black tea brands. Int J. food safety, 13: 226-231.

Jayawardhane, S.A.D.P.S., Madushanka, K.P.C., Mewan, K.M., Jayasinghe, S.K., Karunajeewa, D.G.N.P. and Edirisinghe, E.N.U. 2017. Determination of Quality Characteristics in Different Green Tea Products Available in Sri Lankan Supermarkets. Kooragodage Mudith Mewan, 10:15-31.

Karori, Y. D. Kim, M. S. Shin, B. A. Chay, K. O. Ahn, B. W., Liu, W. and Ellis, L. M. 2014. EGCG, a major component of green tea, inhibits tumour growth by inhibiting induction in human colon carcinoma cells. British J. cancer, 84(6): 844-865.

Koo, P.A., Clifford, M. N., Crozier, A., Day, A. J.; Donovan, J.L. and Manach, C., Williamson, G.2004. How should we assess the effects of exposure to dietary polyphenols in vitro? Am J. Clin Nutr, 80: $15-21$.

Lee, L. J. and Lee, S. H. 2008. Extraction Behavior of Caffeine and EGCG from Green and Black Tea. Biotechnology and Bioprocess Engineering. 13: 646649.

Lui, G., Karan, M., Sharma, P. D., Rakesh, D. D., Vyas, S.and Vasisht, K. 2008. Quantitative analysis of green tea polyphenols in indian cultivars. International centre for science and high technology, 8:19-27.

Maheshwari, R., and Ramchandani, R.2018. Effect of concomitant administration of coenzyme Q10 with sitagliptin on 
experimentally induced diabetic nephropathy in rats. Renal failure, 39(1): 130-139.

Molyneux, P. 2004.The use of stable radical Diphenylpicrylhydrazyl (DPPH) for estimating antioxidant activity. Songklanakarin J. of Sci. and technology. 26(2), 211-219.

Neog, M., Das, P., Saikia, G. K., Sarmah, T. C. and Das Bora. D.2018. Documentation of processing methods and Biochemical quality study of Green Tea manufactured by small tea growers of Assam, India. Bull. Env. Pharmacol. Life Sci. 7 (11):1-57

Obaidi, R. S. S., and Sahib, D. H. 2015. Determination of antioxidants activity in tea extract. American J. Biochemistry. 5(3):49-52.

Ošt'ádalová, M., Tremlová, B., Pokorná, J. and Král, M.2015. Chlorophyll as an indicator of green tea quality. Acta Veterinaria Brno. 83(10) :103-109.

Prawira, S., Mesias, M., Cabrera, C. and Henares, J. A. 2018.Healthy properties of Green and White Tea. Food and function,.8(8):22-65.

Rahman, M. M., Kalam, M.A., Salam, M.A. and Rana, M. R. 2013. Aged leaves effect on essential components in green and oolong tea. Int. J. Agril. Res. Innov. and Tech., 3 (2): 54-58

Ruon, B., Lee, J., Lee, K. W., Kim, H. Y.,
Seo, J. A., Kim, S. G. and Choi, K. M. 2010. Effects of green tea consumption on inflammation, insulin resistance and pulse wave velocity in type 2 diabetes patients. Diabetes research and clinical practice, 71(3): 356-358.

Somanchi, M., Phillips, K., Haile, E., and Pehrsson, P. 2017. Vitamin C content in dried and brewed green tea from the US retail market. The FASEB Journal, 31(1):956-965.

Tsuneki, H.; Ishizuka, M.; Terasawa, M., Wu, J.B., Sasaoka, T., and Kimura, I. (2004).Effect of green tea on blood glucose levels and serum proteomic patterns in diabetic $(d b / d b)$ mice and on glucose metabolism in healthy humans. BMC Pharmacol. 26: 4-18

Willson, K. C. and Clifford, M. N. (Eds.). 1992. Tea: Cultivation to consumption. Springer Science and Business Media,43:16-32.

$\mathrm{Xu}, \quad$ S. and Chen, C.W. 2002.Natural antioxidant from tea. In: Natural Antioxidants. Chemistry. Health Effects and Applications (ed.F. Shahidi). AOCS Press Champaign, Illinois, pp.213-223.

Yashin, A., Yash and Nemzer, B. 2011. Determination of antioxidant activity in tea extracts, and their total antioxidant content. American J.Biomedical Sciences, 3(4): 322-335.

\section{How to cite this article:}

Madhusmita Neog, Priyanka Das and Gautam Kumar Saikia. 2020. Changes in Phytochemicals during Processing of Green Tea. Int.J.Curr.Microbiol.App.Sci. 9(01): 414-421. doi: https://doi.org/10.20546/ijcmas.2020.901.045 